\title{
Cattle Density Analysis for Development of Cattle Farming in Coconut Land Area in South Minahasa Regency, Indonesia
}

\author{
Richard E.M.F. Osak, Tilly D. F. Lumy and Franky N.S. Oroh \\ Department of Livestock Agribusiness, Faculty of Animal Science, University of Sam Ratulangi, North Sulawesi, \\ Indonesia
}

\begin{abstract}
In an effort to develop livestock in a region in a developing country, it is necessary to analyze the potential of the area and density of livestock for the development of livestock business in a development area. This study aims to determine the potential of the region regarding cattle livestock density consisting of: economic density, farming density and regional density for the development of beef cattle farming in coconut plantations in South Minahasa Regency. The method used to carry out the analysis used livestock density analysis and analysis of regional potential using the primary and secondary data needed. The results of the study can be concluded based on the calculation of the combination of economic, farming and region densities, it is known that the sub-districts that receive the first priority in the development of beef cattle are the Sinonsayang and Amurang Barat sub-districts including the southern part of South Minahasa Regency, because this region can develop cattle farming and forage for both grasses and legumes in coconut fields which are mostly located in this region, which can be applied in an integrated manner through the coconut and beef cattle (coco-beef) integration system model. Whereas in Tatapaan Subdistrict and other sub-districts in the North and East regions of South Minahasa Regency it is not a priority for cattle development, because this region is more dominant with clove plantations and food crops such as paddy fields and other food crops.
\end{abstract}

Keywords—cattle density, coconut land, farming.

\section{INTRODUCTION}

North Sulawesi Province, Indonesia sets coconuts as one of the leading commodities. The area of coconut plantation in North Sulawesi is around 270 thousand hectares (Marbun, 2014). Most of the coconut area is only cultivated in monoculture even though it has the potential of integration with livestock (Polakitan, 2012 and Salendua et al., 2018), even the land under coconut trees is only overgrown with vegetation for wild pastures both grass and local legume that grows wild, although the yield and quality of these types of forages are low and some of them are low edible for cattle, but due to lack of forages then the farmers are forced to feed or provide feed for local species (Osak, et al. 2018).

The potential of livestock in South Minahasa Regency is quite adequate, especially cattle, where according to BPS data in 2016 there were 17,345 (BPS, 2017), as one of the largest areas and has the potential for cattle development because of the availability of land in the coconut area which can be used as land for forages and feed crops. Potential areas for developing cattle in South Minahasa Regency are in the area of extensive coconut plantations, which is the influence of the potential of the region on the capacity and density of cattle in the South Minahasa Regency.

Through this research, it is expected to obtain findings and innovations, which consist of: (1) the density of cattle that is divided into three types, namely economic density, farming density and regional density; (2) the potential for developing forage crops in coconut fields; and (3) the potential of the region for the development of beef cattle business in coconut land areas in South Minahasa Regency. The research problems are as follows: (1) How is the level of cattle density divided into three types, namely economic density, farming density and regional density in South Minahasa Regency; (2) How wide is the potential of the development area of cattle in the coconut plantation area in South Minahasa Regency.

The potential for developing livestock production, including farming the cattle-plant integration system, especially with plantation crops in Indonesia, is very large, supported by the potential of land resources for agricultural development, which is 100.7 million ha, which can feed biomass for cattle about 1-3 head / ha throughout the year. If not utilized, agricultural waste will become a problem and obstacle in agribusiness, because at the time of harvest it is wasted and becomes a polluter (BBLSBP, 2009). In addition, cow manure can be processed into bioslurry and biogas, according to Osak and Hartono (2016) that contribute to environmental 
sustainability is reduction in greenhouse gas emissions (GHG). Greenhouse gas emissions cause of global warming lately. Global warming is warming of the earth's atmosphere, due to accumulation principally of carbon dioxide and methane. Meanwhile, diversified systems according to FAO (2001) consist of components such as crops and livestock that coexist independently from each other.

\section{MATERIALS AND METHODS}

This research was carried out on cattle farms in South Minahasa Regency, North Sulawesi Province, Indonesia, where 3 (three) sample sub-districts were selected which had the most cattle population in the East, Central and West regions, namely Sub District of Tatapaan (North region), Sub District of West Amurang (Central region) and Sub District of Sinonsayang (Southern region). The data used in this research includes primary data and secondary data. Sources of data collected are primary data from farmers and secondary data from relevant agencies that are related to this research.

Economic valuation methods use primary data obtained from direct observation in the field, with the method of in-depth interviews with respondents based on the questionnaire that has been prepared in accordance with the objective of the study (Hidayatullah, et al., 2011). Determination of sample villages and sample farmers was carried out by purposive sampling. The sample villages were selected by the criteria of the village which had a large cattle population, while the sample farmers with the criteria of having cattle and coconut plantations.

This study analyzed the potential for developing cattle based on livestock density using the analytical method used by Ashari et al., (1995), where livestock density is divided into three types, namely (i) economic density; (ii) farming density; and (iii) regional density, based on other statistical and secondary data, the formula can be seen in Table 1.

Table 1. Formulas and Criteria for Cattle Density

\begin{tabular}{|c|c|c|c|}
\hline No. & Description & Formula & Criteria \\
\hline 1. & $\begin{array}{l}\text { Economic } \\
\text { density }\end{array}$ & $\frac{\Sigma \text { cattle population }\left(A U^{*}\right) \times 1000}{\text { Epeople pupulation }}$ & $\begin{array}{l}\text { - } \quad \text { Nery density }(>300) \\
300) \\
\text { Middle density }(50- \\
100) \\
\text { - } \\
\text { Rarely density }(<50) \\
\end{array}$ \\
\hline 2. & $\begin{array}{l}\text { Farming } \\
\text { density }\end{array}$ & $\frac{\sum \text { cattle population }(A U)}{\text { The area of arable land }(\text { ha })}$ & $\begin{array}{ll}- & \text { Very density }(>2) \\
\text { - } & \text { Normal Density }(1-2) \\
\text { - } & \text { Middle density }(0,25-1 \\
& \text { Rarely density }(<0,25)\end{array}$ \\
\hline 3. & $\begin{array}{l}\text { Regional } \\
\text { density }\end{array}$ & $\frac{\sum \text { cattle population }(\mathrm{AU})}{\text { Territory area }\left(\mathrm{km}^{2}\right)}$ & $\begin{array}{ll}- & \text { Very density }(>50) \\
\text { - } & \text { Normal density }(20-50 \\
\text { - } & \text { Middle density }(10-20) \\
\text { Rarely density }(<10)\end{array}$ \\
\hline
\end{tabular}

*) $\mathrm{AU}=$ animal unit.

\section{RESULTS}

The environment and climate in South Minahasa supports the development of tropical agriculture. In general, commodity crops and plantations cultivated in this area are food crops (rice, corn, potatoes, cassava, sweet potatoes, peanuts and soybeans), horticultural plants (carrots, beans, spices and onion stems), fruit plants (banana, pineapple, orange, avocado, papaya, mango, durian and rambutan), and plantation crops (coconut, cloves, and vanilla).

South Minahasa Regency has the highest planting area of coconut which reaches 45,041 ha, with total production per hectare of 49,375 tons. Corn is a food crop that has the largest harvest area among other types of food crops, which is as much as 20,882 ha with a total production of 3.94 tons per hectare.

Coconut plants have the largest planting area in South Minahasa Regency, because this regency is one of the centers of coconut production in North Sulawesi province. Coconut plant area has great potential for cattle development, because the area can be planted with grass and legumes for forage under coconut trees. Productivity of Pennisetum purpureum cv. Mott in coconut field that has been fertilized with cattle manure based compost, produces the yield of fresh forage per year can reach $661,947.64 \mathrm{~kg}$ per hectare per year, then the stocking rate per hectare of land under coconut trees can be given to around 45.34 heads of cattle a year (Osak et al., 2018)

The development of cattle in the research area can be done by taking into account the existing values and density criteria of livestock. Determination of values and criteria is based on potential economic density, farming density, and regional density in a region. The results of the study on the value and density criteria of cattle in South Minahasa Kabupaen the results of the analysis can be seen in Table 2.

\section{Table 2. Values and Levels of Cattle Density in South} Minahasa Regency

\begin{tabular}{lrccccc}
\hline \multirow{2}{*}{$\begin{array}{l}\text { Sample Sub } \\
\text { District }\end{array}$} & \multicolumn{2}{c}{ Economic density } & \multicolumn{2}{c}{ Farming density } & \multicolumn{2}{c}{ Regional density } \\
\cline { 2 - 7 } & Value & Level & Value & Level & Value & Level \\
\hline Tatapaan & 92,75 & Rarely & 0,26 & Rarely & 11,10 & Medium \\
Amurang Barat & 236,24 & Medium & 0,21 & Rarely & 14,25 & Medium \\
Sinonsayang & 143,33 & Medium & 0,05 & Rarely & 5,91 & Rarely \\
\hline
\end{tabular}

The economic density of the sample sub-districts in South Minahasa Regency is in the rarely and medium level categories, farming densities generally include level rarely, and regional density including still rarely and medium density. This shows that economic density for cattle is still rarely and medium density compared to the population. If seen from the density of farming, which is generally still rarely density, so it still has a great opportunity to continue to be developed, whereas it is 
seen from the available arable land area that is still classified as rarely and medium density so it is still possible to accommodate cattle to be developed.

South Minahasa Regency is still feasible to develop its potential for cattle. But the data and assessment for each sub-district will produce different information on each density in the economy, farm and regional density. Districts that are economically included are still rarely in Tatapaan Subdistrict, while West Amurang and Sinonsayang Sub Districts are of medium level density for cattle. For farming densities, the three sample subdistricts are included in the rarely density criteria, so that cattle are still possible to be developed.

When viewed from the density of the region, there is no densely populated sub-district, where the District of West Amurang and Tatapaan are classified as medium density density areas, while the Sinonsayang District is still rarely density. This shows that the three sample sub-districts still have potential in developing cattle. This information can provide an alternative in the development of cattle should be done more intensively, so that the potential of the area is used more optimally and the use of coconut plantation crops can be suggested by application to farmers, done by groups of farmers and coconut plantation companies especially Sinonsayang District which has several companies coconut plantations both state-owned companies (BUMN or Badan Usaha Milik Negara in Indonesian) and private companies have business land use rights (HGU or Hak Guna Usaha in Indonesian).

The results of other studies reported that the development of beef cattle can be done through increasing land potential, human resources, and feed patterns. Mukson et al. (2008), that the factors that influence the development of beef cattle by $92.3 \%$ are influenced by land area, availability of forage, labor, and capital. This shows that the extent of land availability and the potential of agricultural waste produced is an opportunity that can be utilized for the development of beef cattle farming including in South Minahasa Regency.

Based on the value of the key characterization criteria, the assessment of the criteria for the density of cattle for all sample sub-districts fulfills the requirements for the development of beef cattle. This assessment shows that all sample sub-districts in Tatapaan, West Amurang and Sinonsayang meet the criteria for cattle development. Based on all the factors analyzed, it is known that all subdistricts in South Minahasa Regency have the potential to develop beef cattle. The results of the calculation of a combination of economic, farming and regional densities are known that the sub-districts that receive the first priority in the development of beef cattle are the Sinonsayang and Amurang Barat sub-districts which belong to the southern part of South Minahasa Regency because this area can develop cattle farming and fodder both grasses and legumes in coconut fields are mostly located in this region which can be applied in an integrated manner through a model of the integration of cattle and coconuts (coco-beef). Whereas in Tatapaan Sub District and other sub-districts in the North and East regions of South Minahasa Regency it are not a priority for cattle development, because those regions are more dominant with clove plantations and food crops such as paddy fields and other food crops.

The results of the analysis above are based on the potential of effective coconut land. However, this condition needs to be supported by forage technology. The results showed that the land under the coconut trees had not been utilized so that cattle only consumed agricultural waste and grass that grew wild. This phenomenon also occurs in other regions, that utilization of vacant land for plantations has not been maximized.

Land under coconut trees in South Minahasa Regency can be utilized for forage development. This approach shows the development of cattle through the integration of coconut-cattle in the research area. The integrated farming system approach can increase productivity and profitability compared to conventional agriculture. The integrated farming system approach causes improvements in household nutrition, income and job creation. The importance of the role of integrated crop-livestock systems for sustainable development, and that integrated crop-livestock systems, implying a diverse range of integrated ecological, biophysical, socio economic conditions, have been a foundation of agriculture for hundreds of years (FAO, 2010).

Livestock management integrated with livestock-crop integration systems, both technically and economically feasible to be developed. This system produces additional work for family labor, and minimizes the risks associated with conventional agricultural systems. Integrated management shows livestock development which leads to the concept of sustainable livestock which includes important components of socio-economic and environmental aspects. Studies that have been carried out on the assessment of sustainable integrated farming are in accordance with quantitative environmental standards and socio-economic benchmarks.

\section{CONCLUSION}

The combination of economic, farming and regional densities is known that the sub-districts that receive the first priority in the development of beef cattle are Sinonsayang and Amurang Barat sub-districts including the southern part of South Minahasa Regency, because this region can develop good cattle farming and forage 
grass and legumes in coconut fields which are mostly located in this region through a system of integration of coconuts and beef cattle (coco-beef integration system). Whereas in Tatapaan Subdistrict and other sub-districts in the North and East regions of South Minahasa Regency it is not a priority for cattle development, because this region is more dominant with clove plantations and food crops such as paddy fields and other food crops.

\section{ACKNOWLEDGEMENTS}

We thank the Rector of Sam Ratulangi University for the PTUU (Penelitian Terapan Unggulan Unsrat) Research Grant in 2018 which has funded the research that produced this paper.

\section{REFERENCES}

[1] Ashari E, Juarini E, Sumanto, Wibowo, Suratman. 1995. Guidelines for Analysis of the Potential Areas of Livestock Distribution and Development. Center for Animal Research and Directorate of Animal Husbandry Development and Development, Jakarta.

[2] BBLSBP, 2009. Perspective of Agricultural Land Support and Technological Innovation in the System of Integration of Palm, Rice and Cocoa-Based Crops. Proceedings of the National Workshop on Dynamics and Performance of Animal Integration Systems Plants: Rice, Palm, Cocoa. Center for Animal Husbandry Research and Development. Bogor.

[3] BPS, 2017. Report on the Results of the North Sulawesi Agricultural Census. Central Bureau of Statistics. Manado.

[4] FAO, 2001. Mixed Crop-Livestock Farming: A Review of Traditional Technologies based on Literature and Field Experience. Animal Production and Health Papers 152. FAO, Rome.

[5] FAO, 2010. Sete Lagaos "Consensus" on Integrated Crop-Livestock-Tree Systems form Sustainable Development (IC-LSD). An international consultation on integrated crop-livestock systems for development-The way forward for sustainable production intensification. Integrated Crop Management Vol.13-2010. FAO, Rome.

[6] Hidayatullah, T., R.Y. Suryandari, A.C. Fitriyanto, and I. Nahib, 2011. Balance sheet mapping and economic valuation of small island resources. Geografia OnlineTM Malaysia Journal of Society and Space 7(1):87-92.

[7] Marbun, J., 2014. Coconut Land in North Sulawesi Threatened Over Land Function. http://www.republika.co.id/berita/nasional/daerah/14/ 03/19/n2nur6-kebun-kelapa-sulut-terancam-alihfungsi-lahan accessed on October 2, 2018.
[8] Mukson, S. Marzuki, P.I. Sai, and H. Setiyawan. 2008. Factors Affecting the Potential of Beef Cattle Development in Kaliori District, Rembang Regency, Central Java. J. Indon. Trop. Anim. Agric. 33(4):305312.

[9] Osak, R.E.M.F., B. Hartono, 2016. Sustainability Status Assessment (SAA) in the integrated farming system of dairy-cattle and horticultural-crops in Indonesia. International Journal of ChemTech Research 9(8):575-582.

[10] Osak, R.E.M.F., S.D. Anis and A. Rumambi, 2018. Productivity of dwarf elephant grass (Penis etum purpureum cv. Mott) and coconut (Cocos nucifera) in Coconut-Beef Cattle Integrated Farming System (Coco-Beef IFS) in South Minahasa, Indonesia. International Journal of Environment, Agriculture and Biotechnology 3(5):1874-1878.

[11] Polakitan. D., 2012. Analysis of Integrated Farming of Plants and Livestock in the Coconut Plantation Area in North Sulawesi. Pastura 2(2):70-73.

[12] Salendua, A.H.S., F.H. Elly, R.E.M.F. Osak and I.D.R. Lumenta, 2018. Cattle Farm Development by Forages Cultivation on Coconut Land Based on Carrying Capacity in West Bolangitang, Indonesia. International Journal of Environment, Agriculture and Biotechnology 3(3):1139-1144. 